\title{
Non-explosive training Grenade for the Schools of the Colombian Military Forces and Police
}

\author{
Granada de entrenamiento no explosiva para las escuelas de las \\ Fuerzas Militares y de Policía de Colombia
Granada de treinamento não explosivo para as Escolas das Forças Militares e Polícia da Colombia

\author{
Fabián Garay-Rairan ${ }^{1}$ \\ Julián Conde ${ }^{2}$ \\ Diego Parra ${ }^{3}$ \\ Nathalie Tarazona ${ }^{4}$
}

Received: October $01^{\text {st }}, 2020$

Accepted: December $15^{\text {th }}, 2020$

Available: May $5^{\text {th }}, 2021$

How to cite this article:

F. Garay-Rairan, J. Conde, D. Parra, N. Tarazona, "Non-explosive training Grenade for the Schools of the Colombian Military Forces and Police,"

Revista Ingeniería Solidaria, vol. 17, no. 2, 2021. doi: https://doi.org/10.16925/2357-6014.2021.02.03

Research article. https://doi.org/10.16925/2357-6014.2021.02.03

1 ESJIM Research Group. Research Department. Non-Commissioned Officers School Colombian Police.

Email: esjin.arein@policia.gov.co

ORCID: https://orcid.org/0000-0001-8863-5673

CvLAC: https://scienti.minciencias.gov.co/cvlac/visualizador/generarCurriculoCv.do?cod_rh=0001492284

2 INTEMIL Research Group. Research Unit. Non-Commissioned Officers Military School.

Email: jefeinvestigacion@emsub.edu.co

ORCID: https://orcid.org/0000-0003-1774-499X

CVLAC: https://scienti.minciencias.gov.co/cvlac/visualizador/generarCurriculoCv.do?cod_rh=0001755456

INTEMIL Research Group. Research Unit. Non-Commissioned Officers Military School.

Email: investigador.tec@emsub.edu.co

ORCID: https://orcid.org/0000-0001-5766-4316

CvLAC: https://scienti.minciencias.gov.co/cvlac/visualizador/generarCurriculoCv.do?cod_rh=0001515163

$4 \quad$ INTEMIL Research Group. Research Unit. Non-Commissioned Officers Military School. Military School.

Email: asesorasemilleros@emsube.edu.co

ORCID: https://orcid.org/0000-0002-2113-4724

CVLAC: http://scienti.colciencias.gov.co:8081/cvlac/visualizador/generarCurriculoCv.do?cod_rh=0000129 301 


\section{Abstract}

Introduction: The paper is a product of the research "Non-explosive training grenade Design for the practice and launch exercise in the training schools of Colombian military forces" carried out in the Escuela Militar de Suboficiales during 2017 and 2020.

Problem: Material mishandling during training sessions can lead directly to the injury of training personnel.

Objective: The research aims to design a Non-explosive training grenade to avoid accidents during launching exercises in the training schools of the Colombian military forces and Police.

Methodology: The transmission and reception elements, display, and sounds items were implemented through electronic devices, seeking to obtain a device that mimics the original grenade during training exercises; the IM 26.

Results: 12 prototypes of low-cost non-explosive training grenades were built for the market in ABS material with triggers and ejectors in steel, which emulate, in dimension and weight, a real IM26 grenade.

Conclusion: The prototype meets the minimum usage, size, and mass requirements that emulate the original, the time after being primed, and the execution sound after being released.

Originality: These unique prototypes in Colombia allow mitigating possible incidents in the training school's grenade-throwing exercises.

Limitations: The transmission and reception modules $(433 \mathrm{MHz})$ did not have enough power to transmit the data over a range greater than $50 \mathrm{~m}$; the radiofrequency system SYNAPSE was used.

Keywords: Grenade, Emulation, Non-Explosive, Radiofrequency, Training.

\section{Resumen}

Introducción: El trabajo es producto de la investigación "Diseño de granadas de entrenamiento no explosivas para el ejercicio de práctica y lanzamiento en las escuelas de entrenamiento de las fuerzas militares colombianas" realizada en la Escuela Militar de Suboficiales durante 2017 y 2020.

Problema: En el ejercicio de lanzamiento de granadas de mano, el mal manejo del material durante las sesiones de entrenamiento conduce directamente a una serie de accidentes para el personal de entrenamiento.

Objetivo: La investigación tiene como objetivo diseñar una granada de entrenamiento no explosiva para evitar accidentes en los ejercicios de lanzamiento en las Escuelas de Formación de las Fuerzas Armadas y Policías de Colombia.

Metodología: Los elementos de transmisión y recepción, visualización y elementos de sonido se implementaron a través de dispositivos electrónicos, buscando obtener un alto porcentaje de similitud como lo hace el ejercicio de lanzamiento con la granada original, la IM 26. Resultados: Se construyen para el mercado 12 prototipos de granadas de entrenamiento no explosivas de bajo costo en material ABS con gatillos y eyectores en acero, que emulan en dimensión y peso a una granada IM26 real.

Conclusión: El prototipo cumple con los requisitos mínimos de uso, tamaño y masa que emulan al original, el tiempo después de desbloquearse y el tiempo de ejecución después de su lanzamiento.

Originalidad: Estos prototipos únicos en Colombia permiten mitigar posibles incidencias en los ejercicios de lanzamiento de granadas de la escuela de formación.

Limitaciones: Los módulos de transmisión y recepción $(433 \mathrm{MHz})$ no tenían potencia suficiente para transmitir los datos en un rango superior a $50 \mathrm{~m}$, se utilizó el sistema de radiofrecuencia SYNAPSE.

Palabras clave: granada, emulación, no explosivo, radiofrecuencia, entrenamiento. 


\section{Resumo}

Introdução: 0 trabalho é produto da pesquisa "Desenho de granadas de treinamento não explosivas para a prática e exercício de lançamento nas escolas de treinamento das forças militares colombianas" realizada na Escola Militar para Oficiais Não Comissionados durante 2017 e 2020.

Problema: No exercício de lançamento de granada de mão, o manuseio incorreto do material durante as sessões de treinamento leva diretamente a uma série de acidentes para o pessoal em treinamento.

Objetivo: 0 objetivo da investigação é desenhar uma granada de treinamento não explosiva para evitar acidentes nos exercícios de lançamento nas Escolas de Treinamento das Forças Armadas e Polícia da Colômbia.

Metodologia: Os elementos de transmissão e recepção, visualização e elementos sonoros foram implementados por meio de dispositivos eletrônicos, buscando obter um alto percentual de semelhança como faz o exercício de arremesso com a granada original, a IM 26. Resultados: São construídos para o mercado 12 protótipos de granadas de treinamento não explosivas de baixo custo em material ABS com gatilhos e ejetores de aço, que emulam em tamanho e peso uma granada IM26 real.

Conclusão: 0 protótipo atende aos requisitos mínimos de uso, tamanho e massa que emulam o original, o tempo após o desbloqueio e o tempo de execução após o seu lançamento.

Originalidade: Estes protótipos únicos na Colômbia permitem mitigar possíveis incidentes nos exercícios de lançamento de granadas da escola de treinamento.

Limitações: Os módulos de transmissão e recepção (433 MHz) não possuíam potência suficiente para transmitir dados em uma faixa superior a $50 \mathrm{~m}$, foi utilizado o sistema de radiofrequência SYNAPSE.

Palavras-chave: granada, emulação, não explosivo, radiofrequência, treinamento.

\section{INTRODUCTION}

The exercise of throwing grenades is part of the military instruction received by the members of the training schools of the Military Forces (FF.MM) and the National Police. This exercise is contemplated, for example, in the case of the National Army in the advanced combat course (C.A.C), where students receive advanced military training and acquire specific skills in weapons handling, among others. These mentioned exercises, and especially the one about the grenade launching, due to cost issues, as well as the high risk of an accident occurring, are the starting point for preparing this project.

Therefore, different ways to satisfy this need were considered, keeping in mind that it should be timely, measurable, and achievable for the personnel in training, in the same way, equipment movement restrictions, budget, and institutional sustainability should be anticipated; taking into account the above conditions, the possibility of having an emulation environment that allows for interaction and learning close to reality is estimated $[2,13]$. The use of the different possibilities in simulation and emulation will allow for the training development, monitoring, and evaluating of a plan to optimize training for each student. 
The "Design of a non-explosive training grenade for the practice and launch of Colombian Military and Police forces in schools" is the result of research work at the Escuela Militar de Suboficiales and, accompanied by the research area in methodological structuring and technical execution, managed to produce a prototype grenade that manages to emulate the physical and general operating characteristics of a conventional hand grenade known as IM 26; Figure 1 shows the real grenade.

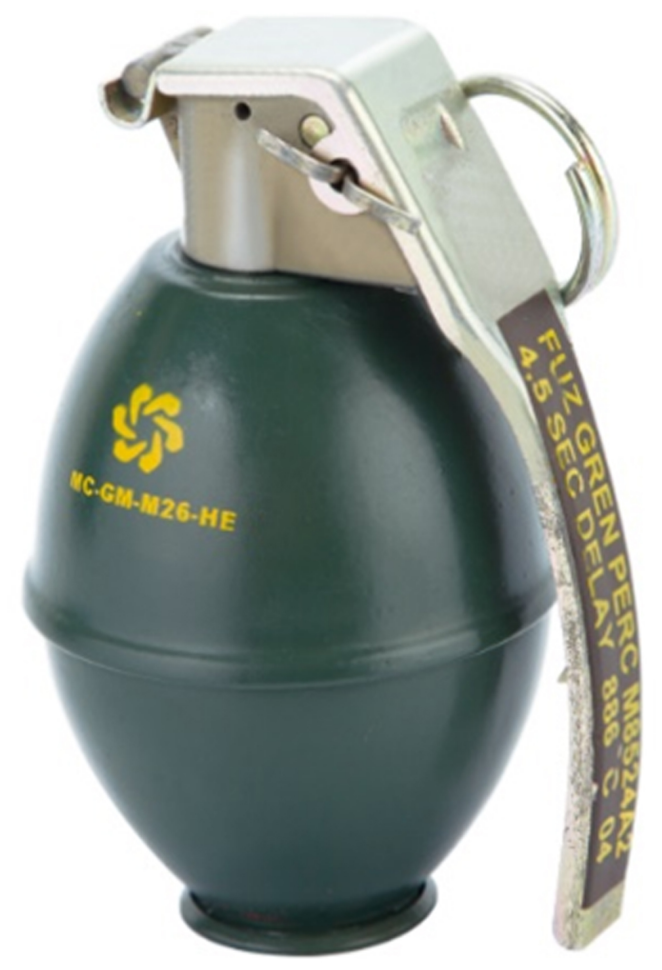

Figure 1. IM26 Hand Grenade.

Source: Image from [10]

The design of the non-explosive emulation grenade consists of a technological mixture that allows for the development of polymer prototyping to be integrated with electronic and telecommunications elements in the transmission and reception of RF signals in freely experimental bands and programming in multipurpose languages; elements that all together achieve a prototype very close to reality, helping to provide a better experience to the military personnel in their training with a reduction of risk of damage by avoiding all potential sources of explosives, decreasing resources, and easing more practice time with regards to the launching of grenades. 


\subsection{Literature review or research background}

A search made in the engineering databases and a publication related to this technology applied to simulation grenades were found, entitled "Long-distance visual ground-based signaling for unmanned aerial vehicles". Regarding similar technologies, two research papers were found: "A Methodology for Effective Analysis of Future Weapon Systems Using a PLAF Based Simulation System", and "Smoke Grenade: A Key Generation Protocol with Artificial Interference in Wireless Networks" [4].

In the development of "Long distance visual ground-based signaling for unmanned aerial vehicles", a long-range visual signal detection system is presented that is suitable for an unmanned aerial vehicle to find an optical signal emitted at the desired landing site for cargo delivery or rescue situations where radio signals or other communication systems are not available or the wind conditions at the landing site need to be reported; the system uses a smoke grenade as a ground signal, which is easy to transport due to its lightweight and small size, but when it is released it provides a means of long-range visual signaling. The system made use of a camera in the UAV with a visual texture feature extraction approach in a machine learning framework to classify image patches as signal or background [7]. This type of grenade system is also used in a vehicle-launched smoke grenade model [12].

Other commercial simulation grenade options available on the market are the Hand Grenade Simulator (HE36Sß). It mildly produces blast, flash, smoke, and sound [18]. Also, the M116A1 - Simulator Hand Grenade can be found that produces a loud report or simulated explosion [9]. Finally, the Hand Grenade (HGSII) uses fragmentation and stun via radio transmission activation [15].

The need to generate methods and systems to analyze and estimate the effectiveness of training, weapons, and equipment is evident, which is why the study "A Methodology for Effectiveness Analysis of Future Weapon System Using a PLAF Based Simulation System" suggests the use of a more effective non-conventional simulation systems for a weapons test. This simulation in PLAF (Product Line Architecture Framework) is more flexible to account for the new features of these weapon systems. As a result, they develop tests to grenade launchers demonstrating that the use of PLAF simulation methodologies allows for a more effective validation of weapons [17]. Other evaluation strategies have involved artificial intelligence to improve these processes; this is the case for the application of neural networks in the tests of hand grenades with fuses [1].

Astudy into the training topic was developed by the Cavalry School of the National Army of Colombia. The objective was evaluating the impact of the implementation of a mobile classroom equipped with simulation tools as a strategy for the training of 
members of this school. As a result, an increase in the number of trained people reduced training times resulting in lower operating costs and greater sustainability [14]. Additionally, a patent search on the Google Patents platform was developed, whose free tool showed the following patents: Training grenade (US5246372A), Practice grenade (US3492945A), Paint dispersing training grenade (US5018449A), and Light and sound grenade (RU5546241). Descriptions of the results will be presented below.

Training grenade (US PATENT US5246372A): A training grenade uses a high-intensity flash to simulate an explosion in a delayed manner when thrown and a sonic device such as a buzzer to indicate armed. Alternative means to simulate the explosion may include sonic devices or radiofrequency sources. An internal power supply and firing circuit connected to an internal timer control the indicator activation or flash by closing an externally controllable switch. The switch is locked in an open position by using a release pin that closes when the pin is removed, or it can keep open by using a pivotally connected safety lever as used in conventional grenades [3].

Practice grenade (US3492945A): The main aim of this invention is to provide an improved training device that gives an adequate level of noise, flash, and smoke for use in simulating the effects of a hand grenade, cheat, or the like. Likewise, provide a device for the production of noise, flash, and smoke that also projects dye drops as a marker in a predetermined pattern of blows on the impacted personnel, which can be recharged with dye, pyrotechnic charges, and propellants for repeated use [6].

Paint dispersing training grenade (US5018449A): This training device consists of a modular grenade that produces a flash, noise, smoke, and a pattern of scoring dye drops determined by the number and arrangement of modules in the set, having scattering passages extending between a central bore and an external surface of the grenade body, a plug threadedly received at one end of the hole, a plunger spring-loaded into the plug, containing a dye capsule placed between the piston and the cap, a detachable release lever that can pivot releasably on the grenade body and coupled with a stop disc on a shaft extending from the piston and a delay mechanism inertial docked between the grenade body and a piston that forcibly breaks the capsule and ejects the dye [5].

Light and sound grenade (options) (RU55462U1): The invention relates to ammunitions, in particular non-lethal light and sound grenades, and can be used for dismantling offenders or impacting on terrorists by creating a psychophysiological exposure (acoustic and light). The proposed light and sound grenade include the means associated with the firing circuit, mounted on the housing meant to create light and sound. The resources for producing light and sound are as a single unit. These grenades are suitable for use in closed or semi-closed areas, providing sufficient light 
and sound effects without the formation of harmful elements, with improved safety and manufacturing operation [8].

\section{MATERIALS AND METHODS}

The design and development of the prototype were carried out in phases starting with the 3D modeling and printing of prototypes in Acrylonitrile Butadiene Styrene (ABS) [22], CAD designs of the final model after the initial validation of the prototypes, molds design for polymer injection ABS, electronic design and assembly and test protocol application. The previously mentioned phases are described below in the text.

\subsection{Prototype in Acrylonitrile Butadiene Styrene (ABS)}

ABS is a thermoplastic categorized by mechanical testing as a rigid and resistant material, completely amorphous and homogeneous, commercial ABS is $95 \%$ pure. It has a tensile strength of $49 \mathrm{MPa}$ and a modulus of elasticity of $1893 \mathrm{MPa}$. The material has excellent thermal stability in terms of weight, up to temperatures of $350{ }^{\circ} \mathrm{C}$, the glass transition temperature is between 100 and $110^{\circ} \mathrm{C}$, the texture of the filament surface consists of small knots that are due to the manufacturing process and the shape of the filament [11]. With this material and using a 3D printer, the prototyping of the piece was generated, where the models presented in Figure 1 were obtained, based on the different types of grenades that are used by the military and police forces in Colombia.

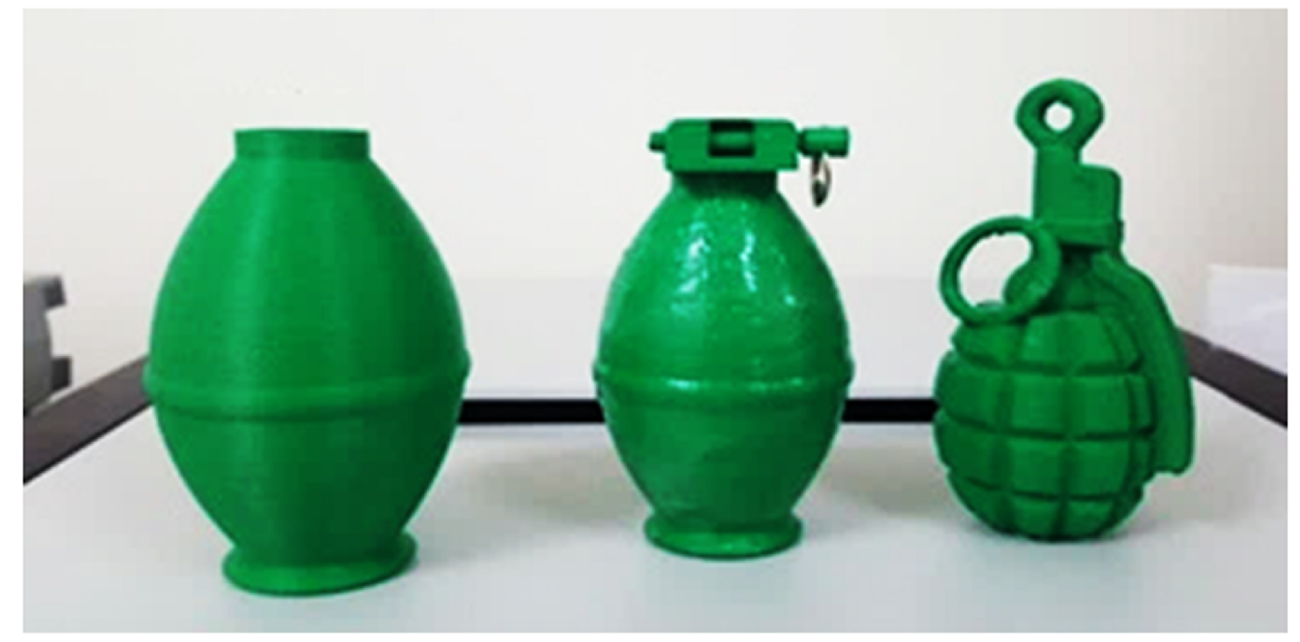

Figure 2. Prototyped with ABS material.

Source: own work 
The central idea is present in a mold system to which ABS type material injected for the creation of the product, a compilation of technical factors of ABS against other materials is shown below in Table 1 of technical data analyzed in the scenario of 3D printing and the use of filaments.

Table 1. Technical characteristics based on 3D printing.

\begin{tabular}{|c|c|c|c|}
\hline Characteristic & PLA & ABS & PETG \\
\hline Hardness & Moderate & Higher & Middle-low \\
\hline Flexibility & Fragile & Moderately flexible & Low \\
\hline Shock resistance & No & Yes & Half \\
\hline Heat resistance & No & Yes $\left(>100^{\circ} \mathrm{C}\right)$ & Yes $\left(80^{\circ} \mathrm{C}\right)$ \\
\hline Printing temperature & $180-230^{\circ} \mathrm{C}$ & $210-250^{\circ} \mathrm{C}$ & $(230-250)^{\circ} \mathrm{C}$ \\
\hline Heated bed temperature & $20-60{ }^{\circ} \mathrm{C}$ & $80-110^{\circ} \mathrm{C}$ & $(60-90)^{\circ} \mathrm{C}$ \\
\hline Warm bed & Optional & Obligatory & Obligatory \\
\hline Clogs the head & Sometimes & Never & Never \\
\hline Absorbs moisture & Yes & Yes & Little \\
\hline $\begin{array}{l}\text { Glass transition tempe- } \\
\text { rature }\end{array}$ & $57^{\circ} \mathrm{C}$ & $104^{\circ} \mathrm{C}$ & $85^{\circ} \mathrm{C}$ \\
\hline Exact melting temperature & $150-160^{\circ} \mathrm{C}$ & $N / A^{*}$ & $(230-250){ }^{\circ} \mathrm{C}$ \\
\hline Printing temperature & $180-230^{\circ} \mathrm{C}$ & $210-250^{\circ} \mathrm{C}$ & $(220-250)^{\circ} \mathrm{C}$ \\
\hline $\begin{array}{l}\text { Exposure to UV rays and } \\
\text { humidity }\end{array}$ & Degradation over time & Degradation over time & Degradation over time \\
\hline Biodegradable & Yes & No & No \\
\hline Recyclable & Yes & Yes & Yes \\
\hline Cutting, filing, sanding & Possible & Possible & Possible \\
\hline Painting, glued & Something possible & Possible & Possible \\
\hline Colors & Wide range available & Wide range available & Can be mixed \\
\hline
\end{tabular}

Source: own work

The criteria set out in the previous table account for the robustness of ABS when compared to other materials that 3D printers commonly use. Nevertheless, a comparison is now presented in the extrusion process with a 3D printer in conjunction with the traditional injection manufacturing process. This comparison also shows the possibility of executing a mass manufacturing process when the grenades are accepted and implemented in the military and police training schools for training exercises.

Some positive aspects of 3D printing are the following: custom manufacturing, low prototyping cost, generation of complex geometries without a problem meaning the possibility of creating structures of different sizes with different geometries, Some 
points are not in favor of 3D printing with disadvantages in the following aspects: a variety of materials, manufacturing speed, not profitable for series production and final finishing, this is how a tendency developed for the injection process of ABS material applying a stainless steel mold that allows for construction in greater volume.

\subsection{CAD Design.}

Using CAD design software for modeling 2D and 3D SolidWorks ${ }^{\circledR}$ parts, the specific model of an IM26 hand grenade with its real dimensions were developed: (measurements are taken from the current grenade, to emulate the physical component) 10.5 $\mathrm{cm}$ high, $6 \mathrm{~cm}$ wide, one-piece ring fuse and green color.
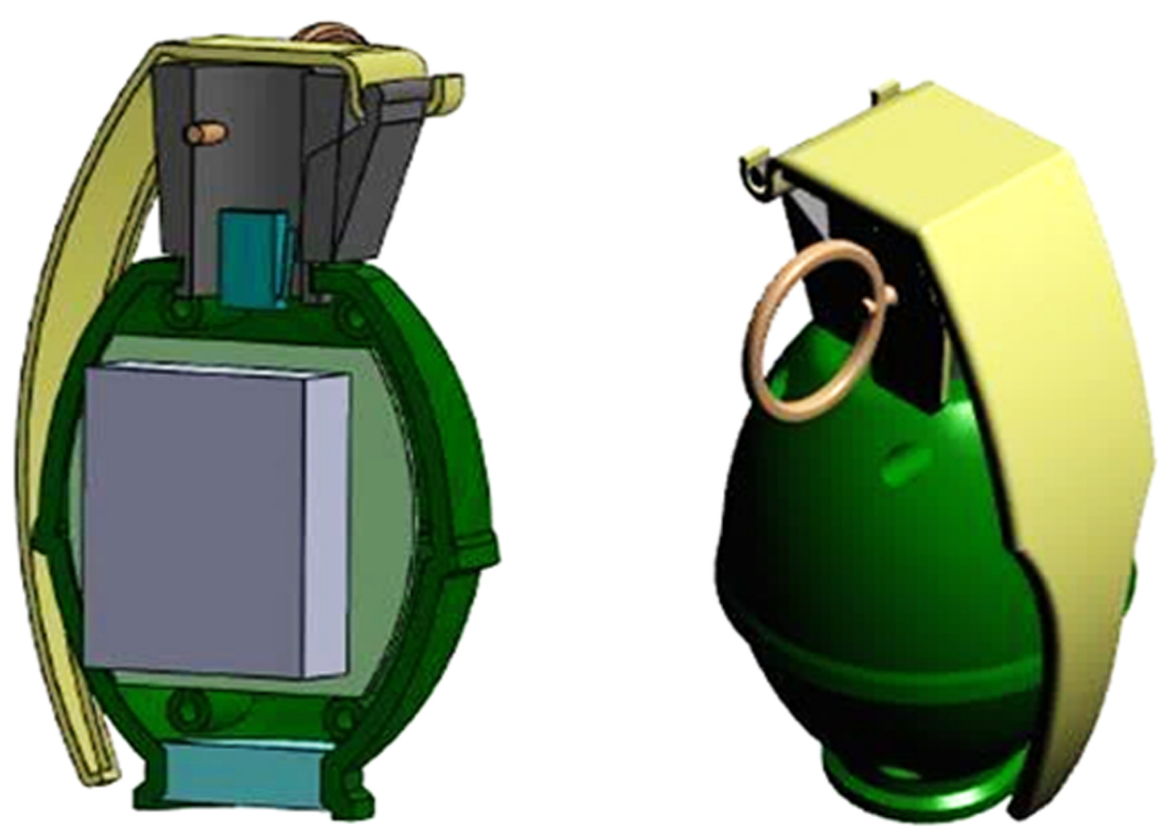

Figure 3. CAD design of the grenade with fuse.

Source: own work

Figure 2 shows the primary development of the grenade model. The chosen models are based on the different hand grenades that have been used in combat exercises. These designs, such as the Pineapple type grenade (MK2) were used as test models to determine the characteristics of the material to be used in production. The same figure shows a similar design to the MK 2 but flat with the adequacy of assurance control, a design that is not on the market, but that was also made to test 
the durability of the material and the ease of producing this device in greater quantity, managing to observe some difficulties such as:

1. Each of the models depicted in the figure has a printing time of more than 4 hours with a conventional $3 d$ printer.

2. Each model is made compactly, therefore, increasing the difficulty of being able to insert the electronic circuits inside them. This gave rise to the need to be able to open the model in two parts, leading to further difficulties with regards to the printing of holes where the screws that would fix the grenade with the circuit inside would be placed.

3. The finish for the final presentation involved manual labor that required deburring, generating more time in each of the products manufactured.

4. When crash testing by dropping it from a height of $6 \mathrm{~m}$, it was noted that the thinner parts of the impression tended to fracture and fragment easily, demonstrating that these parts should be made of a more rigid material, such as metal, for example.

Following the above, the exercise of implementing the first models with 3D [19] printing helped to determine components, determination of times, possible first damage to the final product if it were made with ABS; this is why the creation of a stainless steel mold was used to inject plastic and to help improve production in terms of time and finish. Two molds were created, which allowed for injecting each of the faces that should then be joined through screws, also using metal cutting and bending machines. The upper part of the grenade was designed, as well as the ring and the fuse, with a spring system that emulated the firing of the fuse and that also activated sensors that emitted the necessary signals to complete the process, as shown Figure 3. It is highlighted that the injection mold is made under the figure of an IM-26 type hand grenade (Figure 1), a current grenade used by the public force in the area of operations, as well as in training schools at the real level as at the instructional level.

\subsection{Injection Mold Design}

With the first 3D printer prototypes failing crash testing, the need for the design and elaboration of a new mold for the injection of the ABS material was determined, obtaining a finished product, with exact parts and with the possibility of large-scale production. The material used for the construction of the mold was steel; employing a CNC (Computer Numerical Control), as a result, a steel mold (SAE 1045) was obtained 
for the production of a prototype hand grenade, using tempered detachable a52-54 Rocwel, guided ejection with heat treatment and production capacity of a cavity.

\subsection{Electronic Design}

The development of the electronic circuit comprises several grenade modules, including the system of transmission, reception, processing, supply, display, and audio. The central module used is called Synapse I [16], which is an electronic component used for the communication, sending, and receiving of the signals that are ordered by the sensors, which are located in the upper part of the grenade. They carry out two counting activities, the first corresponding to the time the grenade lasts in the hand of the person who handles it after pulling the pin and the second with the delay time that emulates the detonation action, when it is launched, releasing the fuse or safety lever to activate the detonation hammer.

The principle of operation of the system is Radio Frequency (RF), 250 kbps to 2 Mbps with a radio data transmission rate RF frequency of $2.4 \mathrm{GHz}$ Spread Spectrum Technology (DSSS) Certified by FCC, 1C, and CE Receive amplifier (7 dBm) Transmit amplifier (15 dBm). It is connected to an RPSMA antenna and the network operating system is SNAP. This component has the capacity of 3 miles of open field operation. Additionally, the electronic circuit has the F1T12D2 microcontroller, in charge of processing the information obtained in real-time and allows for the operating conditions of the processes to be carried out to be modified.

The circuit has a power system with a 3.6V battery, which has been designed to be rechargeable, through a charging connector, using a power supply and near to the connection terminals of the sensors that determine the meters. Figure 4 shows the grenade circuit diagram for the reception and transmissions modules, the design of the printed circuit was adjusted to the Synapse device inside the grenade and the battery to supply the modules. 


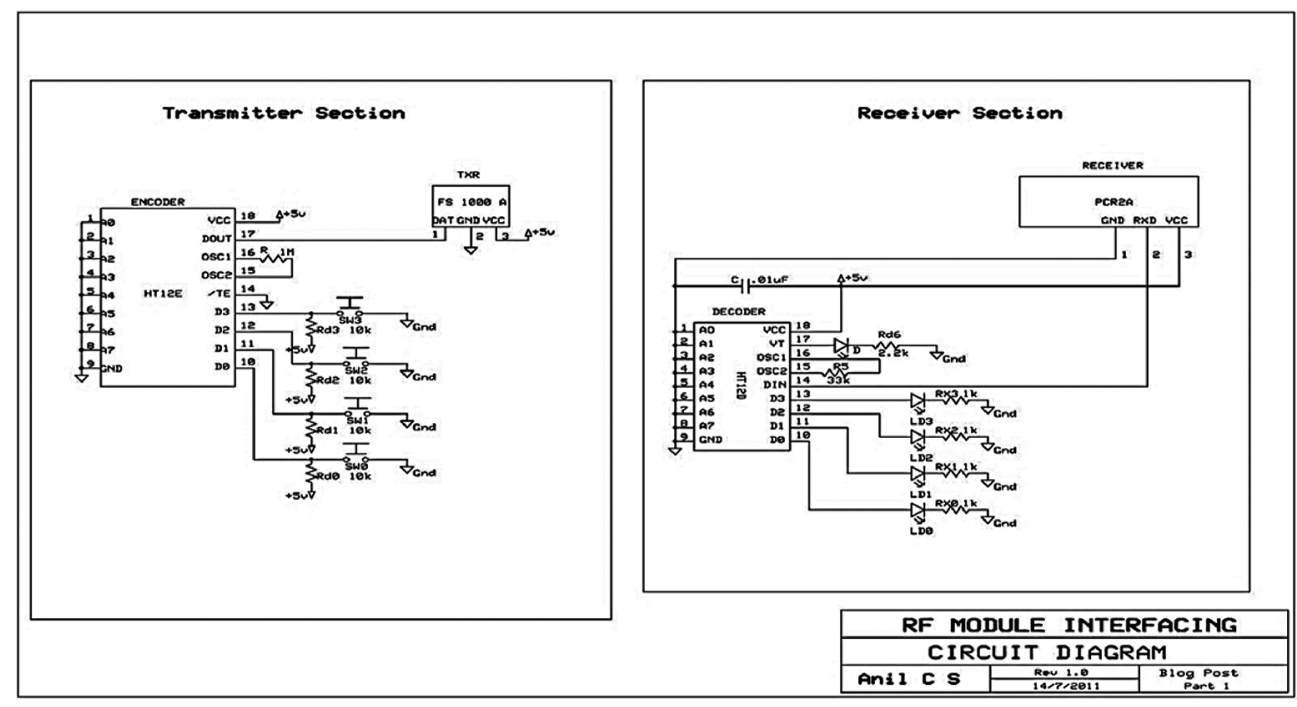

Figure 4. Circuit diagram of the grenade (reception and transmission modules). Source: own work

\subsection{Decoding System}

This system is in charge of signal reception together with the interface for connection to a screen that allows for observing the meters and generates the sound that emulates the explosion. The interface is made in a Cubieboard [21] board which is programmed in Python and is in charge of receiving the signal from the receiver, decoding it and delivering the data that comes directly from the grenade sensors. This interface connects to the screen via HDMI cable and is easy for the user to execute.

\subsection{Audio System}

As the final element of the set, there is the audio system that seeks to emulate the sound that the grenade produces when it is activated and thrown. This sound is between $150 \mathrm{~dB}$ and $170 \mathrm{~dB}$, a datum above the pain threshold; therefore, a system was implemented that could produce a sound power similar to that requested, and a set of active booths connected in parallel and emitting the sound of the explosion were chosen at the same time. Each of the cabins in its datasheet presents a maximum power of $124 \mathrm{~dB}$ with $1300 \mathrm{~W}$ in its woofer or subwoofer, Tw215a reference.

\subsection{Test Protocol}

Through field tests, and once instructors have been trained and trained in handling the prototype of the non-explosive training hand grenade, following the operation and 
instruction manual of the simulation grenade, we proceed to the complementary instruction to impart on the units and thus train the military to carry out their tactical position, assuming the need to apply the security regulations established for the use of hand grenades. To verify the correct operation of the device within the protocol, the following was verified:

- Mechanical compression tests.

- Autonomy of electrical operation.

- Radio frequency range distance.

- Temperature test.

- Humidity test.

- $\quad$ MIL-STD 810 Shock Test, Method 516.

The test conditions are very important, since the correct operation, execution and results of the simulation grenade launch tests depend on them. That is why each one of these conditions, without exception of any, must be simultaneously fulfilled with at least some minimum characteristics stipulated for the correct development of the test. Table 2 presents the test conditions.

Table 2. High-level testing conditions.

\begin{tabular}{|c|c|c|c|}
\hline Id & Condition name & $\begin{array}{l}\text { High level test } \\
\text { condition }\end{array}$ & Description \\
\hline 1 & Charging devices & $0 \%-100 \%$ & $\begin{array}{l}\text { The minimum conditions to carry out the test must be a } \\
\text { minimum of } 15 \% \text { load on the simulation grenade. This will } \\
\text { allow at least } 1 \text { test to be made without any problem. }\end{array}$ \\
\hline 2 & Distance & 0-30 m & $\begin{array}{l}\text { The maximum distance is around } 30 \mathrm{~m} \text { between the } \\
\text { reception module and the simulation grenade because if } \\
\text { this length is exceeded, communication between these } \\
\text { elements will be lost. }\end{array}$ \\
\hline 3 & Launch position & $1.20 \mathrm{~m}$ & $\begin{array}{l}\text { The inner front and side walls will have a height of } 1.2 \mathrm{~m} \text {. } \\
\text { The approximate shoulder height of an average person. } \\
\text { This to fulfill two functions: first, allow the grenade to be } \\
\text { thrown and avoid hitting the wall. The second is that at the } \\
\text { same time it serves to protect the user after the launch in } \\
\text { the emulation of the explosion. }\end{array}$ \\
\hline 4 & Grenade drop zone & Esplanade & $\begin{array}{l}\text { The esplanade area of natural earth must not contain } \\
\text { stones or objects that could damage it. These must-have } \\
\text { objectives for the military to aim and launch on them } \\
\text { (painted circles of different sizes). Particular care should } \\
\text { be taken with rainwater deposits in the test scenario since } \\
\text { if they fell into any of these, there would be the total loss } \\
\text { of the simulation grenade. }\end{array}$ \\
\hline
\end{tabular}


(viene)

\begin{tabular}{|c|c|c|c|}
\hline Id & Condition name & $\begin{array}{l}\text { High level test } \\
\text { condition }\end{array}$ & Description \\
\hline \multirow{4}{*}{5} & \multirow{4}{*}{ Temperature } & \multirow{4}{*}{$\begin{array}{l}\text { Range from } \\
15 \text { to } 35^{\circ} \mathrm{C}\end{array}$} & $\begin{array}{l}\text { Grenades are often introduced in environments with } \\
\text { extreme temperatures, created for both outdoor weather } \\
\text { conditions and indoor industrial infrastructure. }\end{array}$ \\
\hline & & & $\begin{array}{l}\text { A single simulation hand grenade can move up to a tem- } \\
\text { perature of } 35^{\circ} \mathrm{C} \text { on a loading platform or in a transport } \\
\text { vehicle up to a low temperature of } 15^{\circ} \mathrm{C}\end{array}$ \\
\hline & & & Reference MIL-STD-810G \\
\hline & & & $\begin{array}{l}\text { The ambient temperature in Tolemaida ranges from } 21 \text { to } \\
32^{\circ} \mathrm{C} \text {. }\end{array}$ \\
\hline \multirow{5}{*}{6} & \multirow{5}{*}{ IP } & \multirow{5}{*}{ IP 64} & $\begin{array}{l}\text { Special place conditioned for this type of test (an adap- } \\
\text { tation of sound and TV). The prototype works very well } \\
\text { in enclosed spaces since the detonation by means of the } \\
\text { baffles sounds at adequate decibels and allows for the } \\
\text { perception of the student's exercise. }\end{array}$ \\
\hline & & & $\begin{array}{l}\text { It is not recommended to practice the exercise on a } \\
\text { concrete floor since the device may suffer openings in the } \\
\text { joints. It is recommended to use the device on remova- } \\
\text { ble dirt terrain where the device's impact to the ground } \\
\text { can withstand more than six throws without breaking or } \\
\text { opening. }\end{array}$ \\
\hline & & & $\begin{array}{l}\text { It is not recommended to use the device in places with pu- } \\
\text { ddles or mud, due to its IP degree. Water can filter through } \\
\text { the holes and damage the electronic circuit. }\end{array}$ \\
\hline & & & $\begin{array}{l}\text { The training ground available for the EMSUB grenade } \\
\text { court presents an arid terrain condition, where the relative } \\
\text { humidity level when it rains is } 94 \% \text { on average. }\end{array}$ \\
\hline & & & $\begin{array}{l}\text { Therefore, an IP } 64 \text { degree of protection is required, } \\
\text { protected from total dust penetration, and protected from } \\
\text { water spray from any direction, to guarantee operation. } \\
\text { Per this requirement, the test will be carried out. }\end{array}$ \\
\hline
\end{tabular}

Source: own work

\section{RESULTS}

The physical components described previously are part of the grenade fabrication modular design criteria. To emulate the original grenade weight (440 grams) the electronic device weight was used along with a molded and integrated cast metal plate. Figure 5 shows the final prototype of the grenade and the signal reception systems and HMI. 


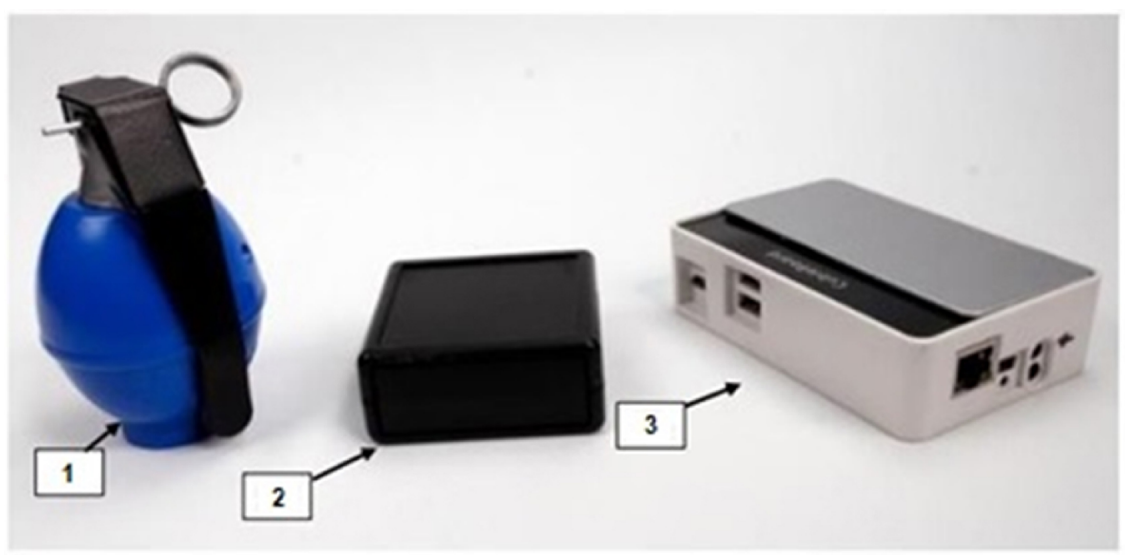

1- Assembled grenade.

2- Receiving system of signals emitted by the circuit.

3- CUBIEBOARD - HMI

Figure 5. Final result of the prototype.

Source: own work

\subsection{Mechanical compression tests}

The preliminary test of mechanical compression tests of the designed grenades was carried out to the point where, during the test application process, a significant drop in the load was observed or deterioration was observed in some of the elements of the grenade. The maximum load and deformation results of each grenade obtained are observed in Table 3. The details of the test results can be seen in Figure 6.

Table 3. Maximum load and deformation of grenades.

\begin{tabular}{cccc}
\hline Element & $\begin{array}{c}\text { Maximum reported } \\
\text { load } / \mathbf{N}\end{array}$ & $\begin{array}{c}\text { Maximum vertical } \\
\text { deformation } \mathbf{~ m m ~}\end{array}$ & Condition \\
\hline 1 & 2809 & 3,35 & Two screws \\
\hline 2 & 3662 & 2,61 & Four screws \\
\hline 3 & 2674 & 3,00 & Two screws \\
\hline 4 & 2352 & 2,19 & Four screws \\
\hline Average & 2874 & 2,79 & \\
\hline
\end{tabular}

Source: own work 
A

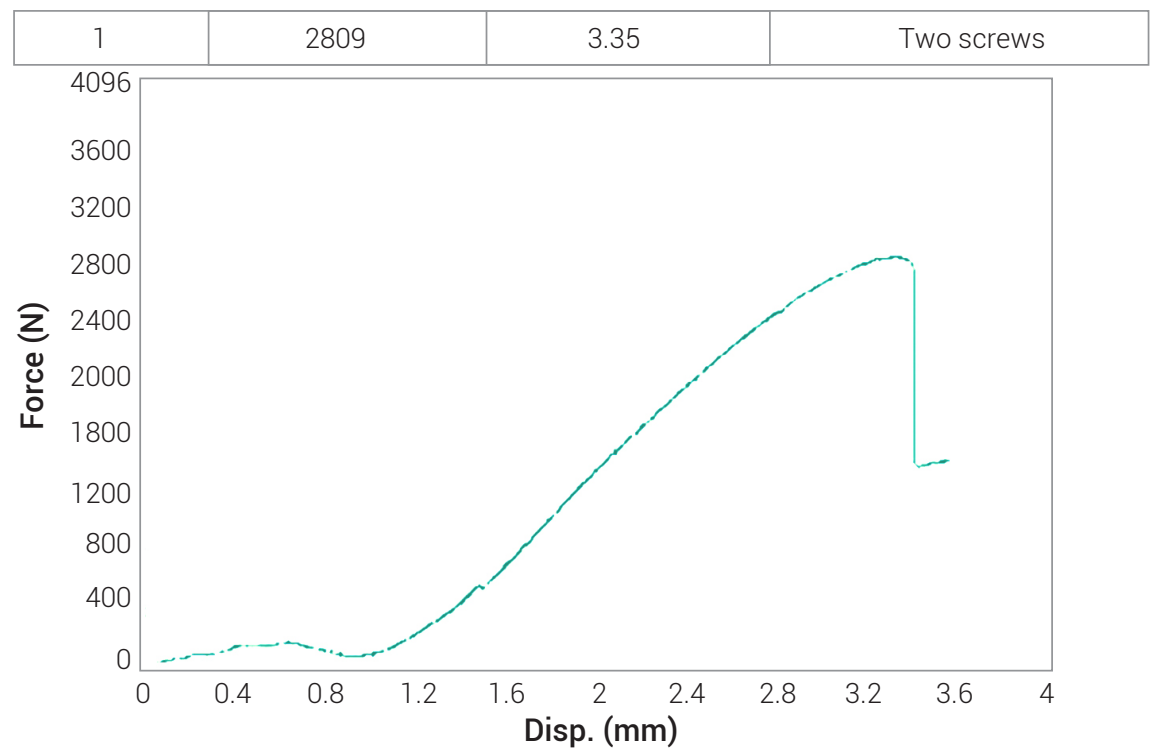

B

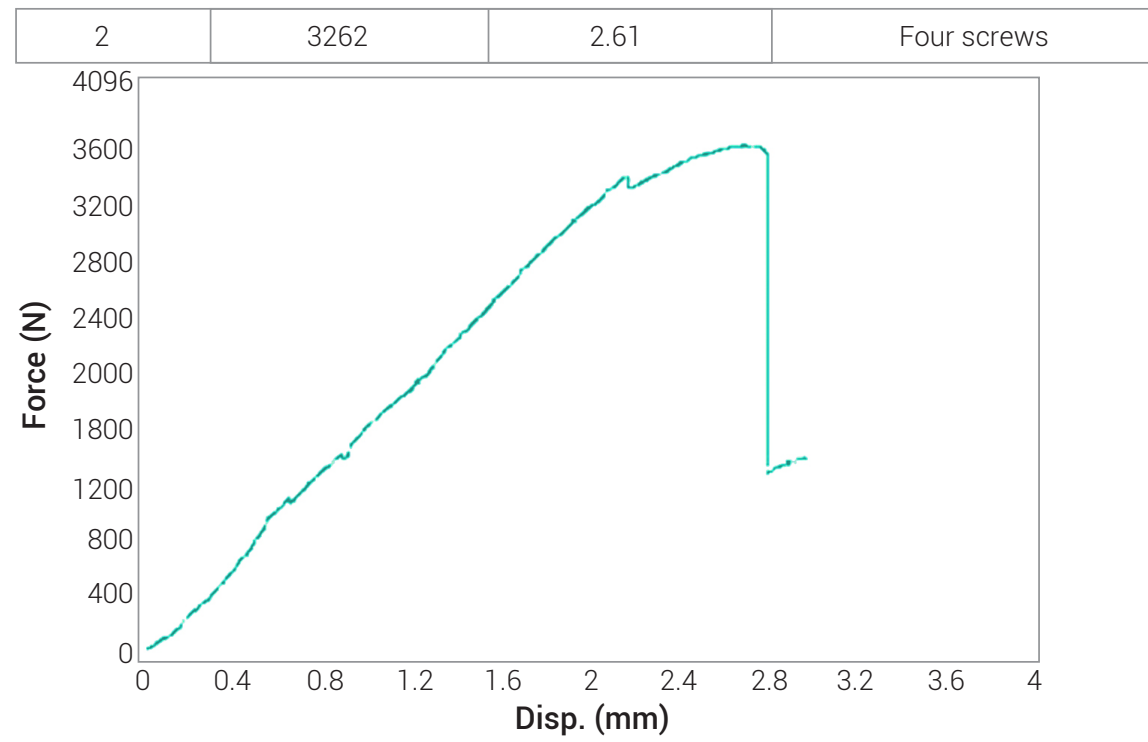

Figure 6. Gasket compression test chart (a) for two screws (b) for four screws.

Source: own work

\subsection{Operational verification}

The operation of the device was tested by interconnecting all the elements described and executing the unlocking of the ring, which causes the first signal to be emitted and is visible on the device screen. Then, when the device is launched, the mechanical system ejects the safety lever and emits the second signal that activates a reverse 
counter of $4.5 \mathrm{~s}$, also displayed on the screen (HMI). Once this count finishes, the sound that emulates the explosion is emitted and is reproduced in the set of active booths, the result of the verification can be seen in Table 4.

Table 4. Performance check results.

\begin{tabular}{cc}
\hline Item & Characteristics \\
\hline Time & 4.5 Second configurable \\
\hline Range & Maximum $50 \mathrm{~m}$ \\
\hline Reception & Signal received \\
\hline Prosecution & Sound emission \\
\hline Sound emission & Verified \\
\hline
\end{tabular}

Source: own work

\subsection{Humidity test}

Based on the different verification and testing criteria of the MIL-STD-810G protocol, a humidity test was performed following the induced 1507,6 procedure (procedure and transit) and natural cycles. It was observed that the device in total water immersion, the liquid leaked through the fold of the two faces and wet the circuit and the battery, therefore, it was determined that it cannot be completely submerged. Subsequently, the test was carried out with a dripper simulating drizzle at a constant speed for 5 seconds where no damage was evidenced in the prototype. Only when the operation is carried out within $5 \mathrm{~cm}$, where it can filter through the holes in the grenade, does water reach the electrical circuit. The closer the drip is operated to the device, the greater the chance of damage and leakage to the electrical system. This test restricts the use of the prototype in open fields with nearby lagoons or in operation in the rain, in Figure 7 you can see the result of the test. 


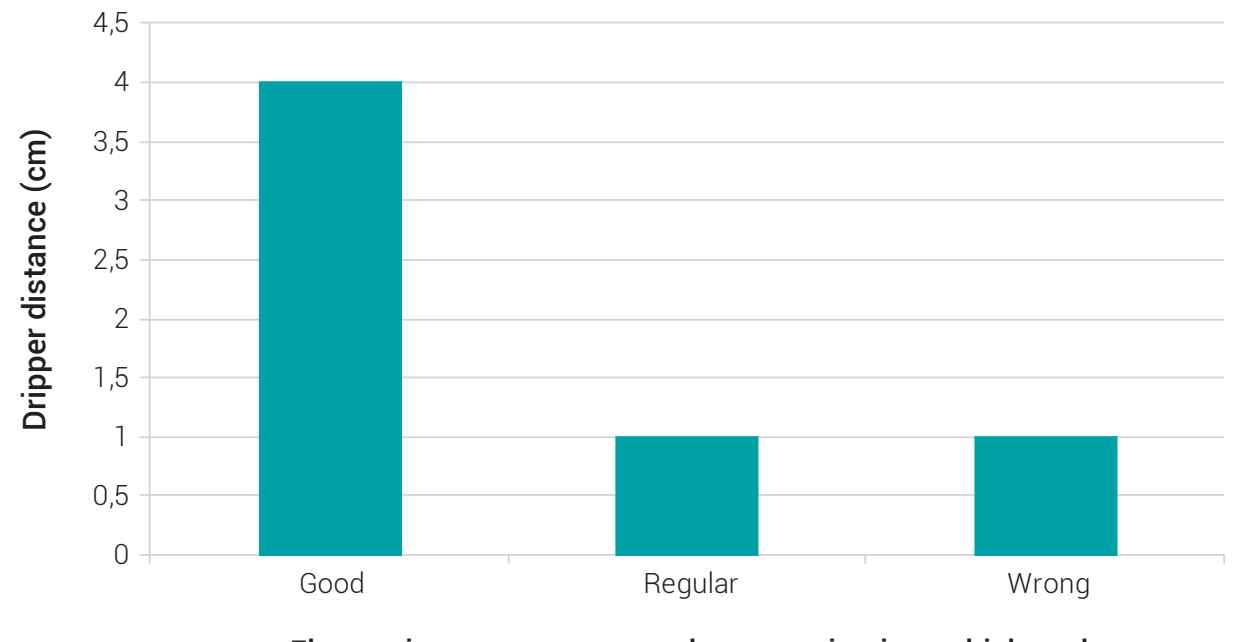

Electronic system status and communication cubieboard

Figure 7. Graphic of the drip test result.

Source: own work

On the $\mathrm{X}$-axis, the behavior of the grenade operating system is express as good, regular, and bad concerning the electrical part and communication with the Cubieboard when employing a dripper. It can be expressed that at a distance greater than 1 to 4 centimeters there is no damage to the System, allowing a signal between the receiver and the emitter; then at less than one centimeter, the liquid filters through the prototype holes, interrupting the signal. The strength of the grenade against heavy rain and gusts of wind were evaluate using standard rain test standards MIL-STD810G, considering a 30 minute drip test.

\subsection{Autonomy test of the energy source}

300-second execution duration tests with 15-minute rest intervals were performed on the device. The test is performed for 8 hours during a day, with the repetition of the exercise during this time (Approx. 53 repetitions). With this test, it was shown that in all the repetitions the transmission was continued, and the reception system captured the signal, which shows a durability of the battery in the estimated time. Taking into account the previous test, the grenade was kept without operating for the same course, (simulating transport and transfer times of the simulation grenade) to check the time in which the grenade presents failures due to low or discharged battery. After performing the exercise, it is deduced that the grenade has more than 9 hours of battery life, with constant handling or leaving it static and without operating. 


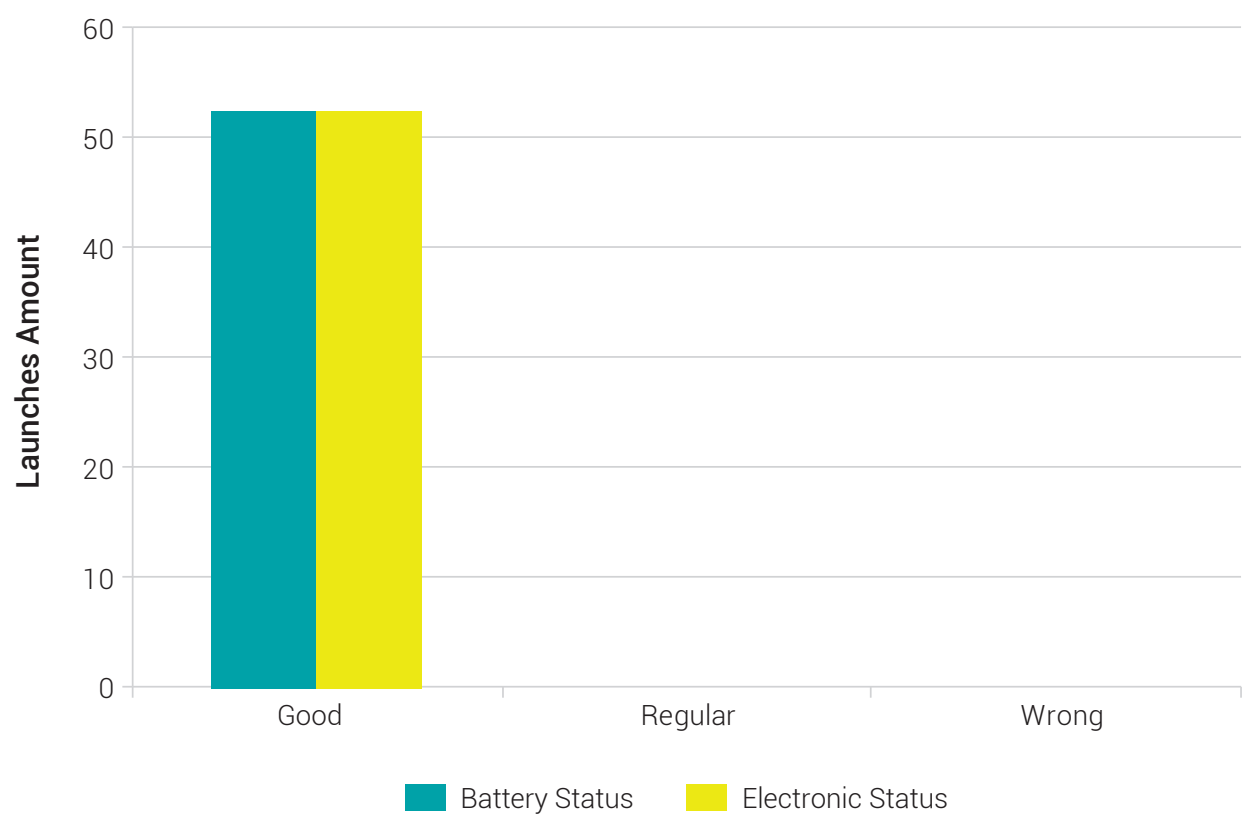

Figure 8. Behavior in tests of autonomy of the power source. Source: own work

An inspection was performed with a spectrum analyzer before testing to determine how congested the channel and its surroundings were on similar frequencies. By running the signal trace, a slight electrostatic noise that operates around $-70 \mathrm{~dB}$ was detected. With this, it was determined that the test carried out is adequate and pertinent to know the ideal operating range and not have noise in the signals acquisition, resulting in successful testing in the rank of 0 to 50 meters.

\subsection{Radio frequency range distance}

Through this trial and applying demarcation of the operating space between $1 \mathrm{~m}$ to $60 \mathrm{~m}$, leaving as a base measurement the radiofrequency system with the Cubeboard for the tests, signal quality is tested for each of the distances, as shown in Figure 9. In the graph, we can see how after $50 \mathrm{~m}$ the signal begins to decrease until it drops to a $0 \mathrm{~m}$ signal at $62 \mathrm{~m}$. Of the launches carried out with suitable personnel, the average, depending on the strength of the military or police, is a launch of approximately $30 \mathrm{~m}$, which makes the prototype viable for simulation in training schools. Through a checklist file, the data was taken considering the radiofrequency communication system versus the distance, and Figure 9 was constructed. 


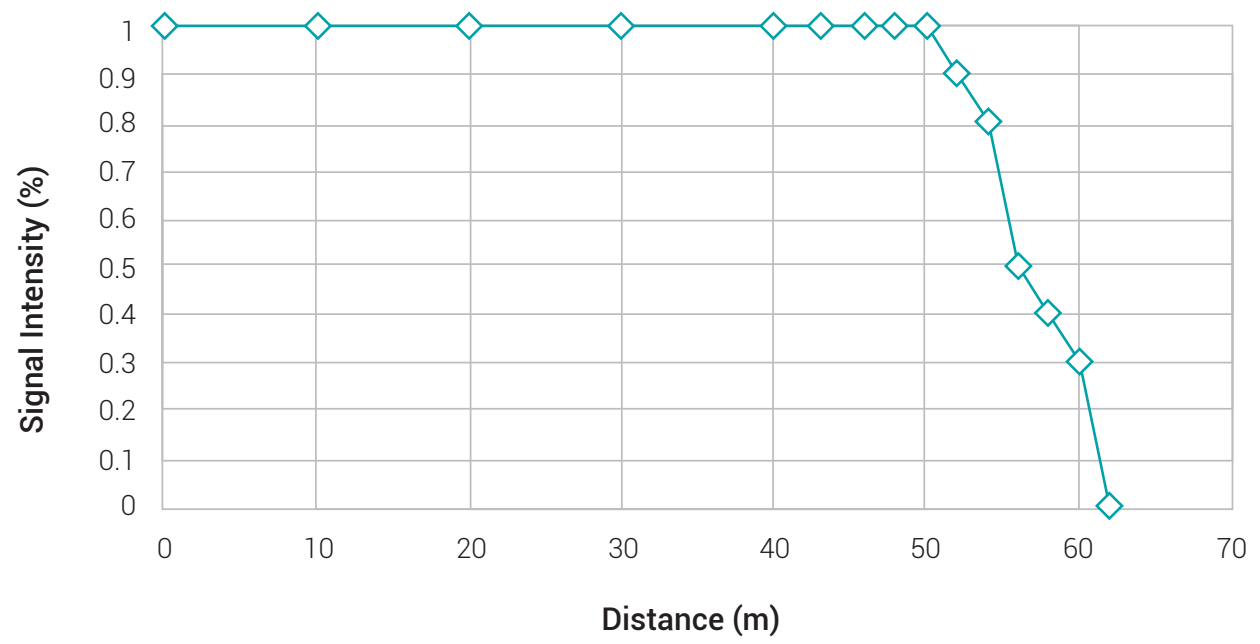

Figure 9. Relationship of signal intensity vs distance.

Source: own work

\subsection{Temperature Test}

This test was essential in the prototype evaluation process due to its possible use in different geographical locations; it considered the thermal resistance tests with a controlled heat source for its realization, from an average ambient temperature of $25^{\circ} \mathrm{C}$ to $64^{\circ} \mathrm{C}$

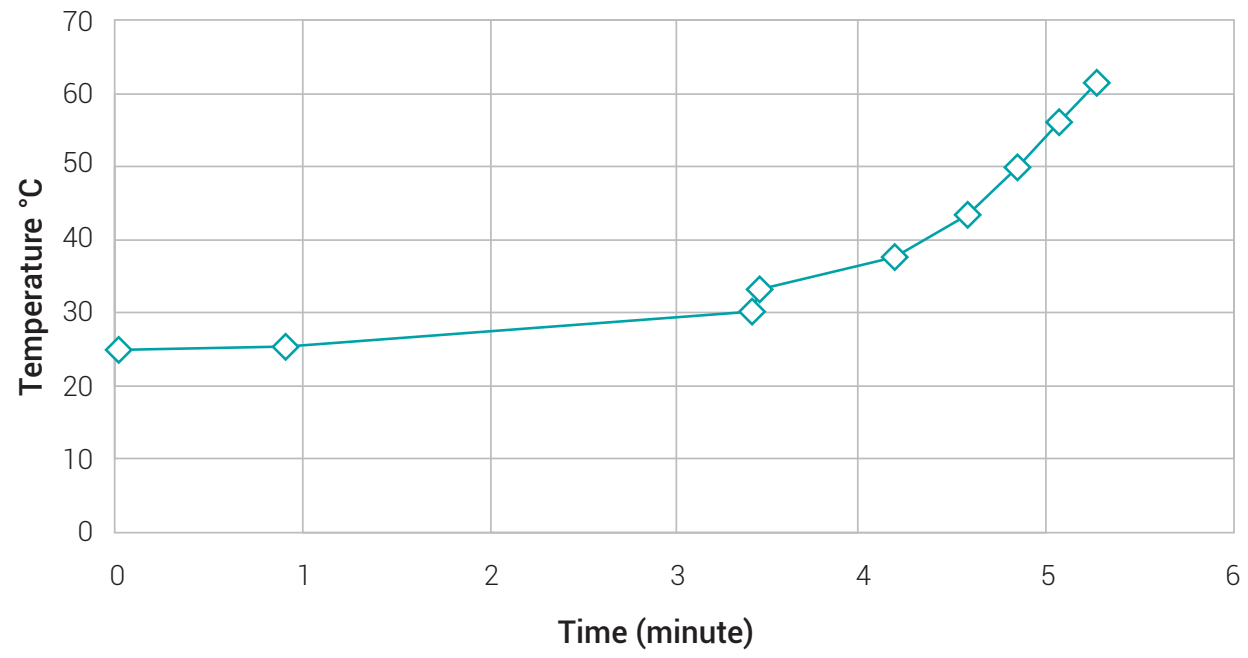

Figure 10. Temperature tests vs time.

Source: own work 
Figure 10 shows the relationship between the heating time of the grenade material versus the temperature in degrees, considering that the zero time starts with the ambient temperature of $24.5^{\circ} \mathrm{C}$. The first minutes do not show significant changes in the communication between sender and receiver, in minute 3 to 6 minutes the temperature increases considerably up to $61.3^{\circ} \mathrm{C}$ maximum test temperature. Despite the abrupt temperature change, the communication between the grenade and the receiver continues without any interference, concluding in this test the functionality of the prototype for extreme temperatures.

\subsection{Crash test}

Based on the different verification and testing criteria of the MIL-STD-810G protocol, a crash test was performed following the procedure I 516.7 (functional shock) with military personnel. Each attendant performed 10 throws between $3 \mathrm{~m}$ and $30 \mathrm{~m}$, thereby calculating the impact speed of the simulation grenade. This test managed to show that the impact after the tenth launch did not damage the transmission system or the power supply, only some minor scratches were perceived on the surface of the device. The evidence of this test is in receiving the signal after the launch. In the exercise, it was determined that the ejecting safety lever element, as well as the safety ring (similar to the real grenade), must be located and reassembled.

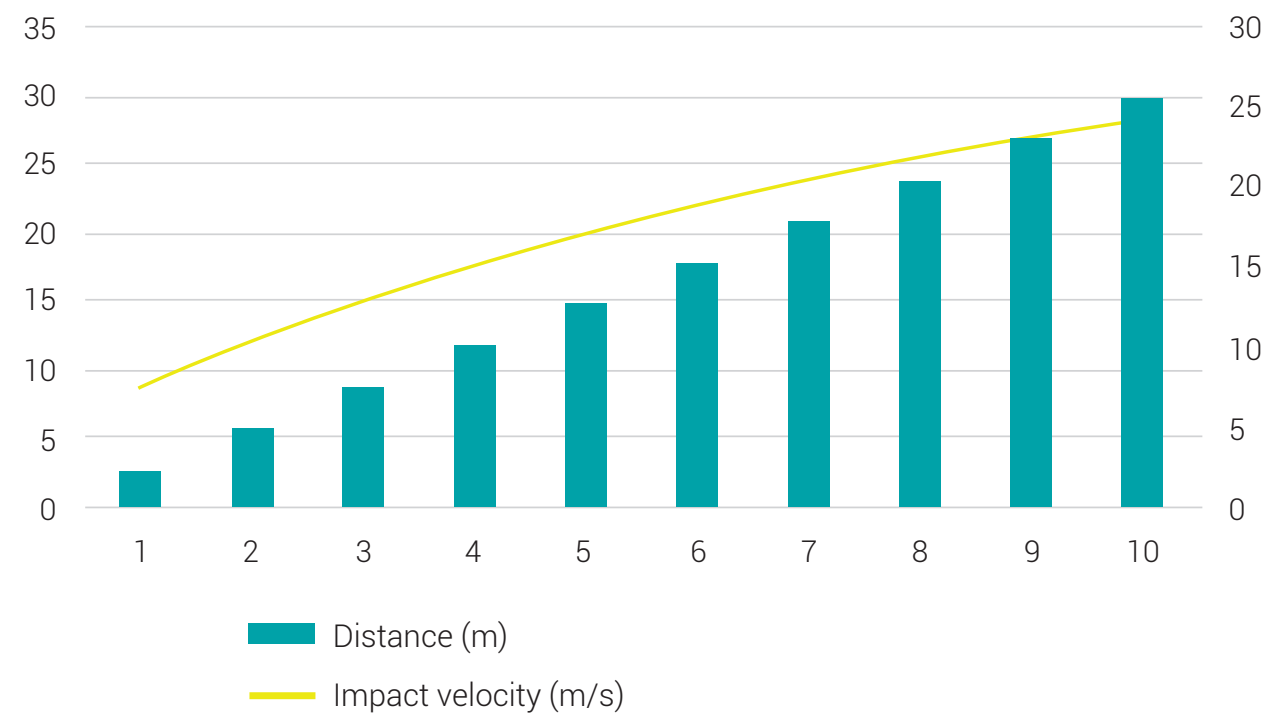

Figure 11. Impact velocity graph.

Source: own work 
The distance and speed employing the exerted force did not generate any change in the electrical and communication system. It is suitable to be launched at a distance of up to $60 \mathrm{~m}$, according to the calculations and studies carried out.

\subsection{Financial evaluation}

This section presents the value established for the non-explosive hand grenade prototype. It did not take into account the costs incurred in the monitor for the detonation time projection, the sound reproduction speakers, and the costs inherent to the investigation and experimental development; with the estimated value is calculated material cost, construction, and incorporation of the program for its operation, Table 5 shows the comparison between the detailed value of an emulation grenade and the real one.

Table 5. Production costs of one device.

\begin{tabular}{|c|c|c|}
\hline Component & Electronic Grenade & Real Grenade \\
\hline Material Injection & $\$ 40.000$ & $\$ 125.000$ \\
\hline Safety clip & $\$ 2.000$ & \\
\hline Toggle hinge and screws & $\$ 7.500$ & \\
\hline Fuse & $\$ 3.500$ & \\
\hline Spring & $\$ 3.200$ & \\
\hline RF Communicator for Tx & $\$ 35.000$ & \\
\hline Tx Power Battery & $\$ 6.800$ & \\
\hline Internal Tx Printed Circuit & $\$ 14.000$ & \\
\hline RF Communicator for Rx & $\$ 35.000$ & \\
\hline CubieBoard & $\$ 124.000$ & \\
\hline Visualization and Audio & $N / A$ & \\
\hline Total & $\$ 271.000$ & $\$ 125.000$ \\
\hline
\end{tabular}

Source: own work

The table evaluated above presents the manufacturing costs of an electronic grenade unit, however, it is significant to understand that the marginal cost that occurs when producing an additional batch is subject to the fact that you will not have to use display systems or audio, as well as the CubieBoard card, that is designed for the operation of four grenades within a launchpad. 


\section{DISCUSSION AND CONCLUSIONS}

The result of the grenade body subjected to the compression stress is evidenced, where when performing stress tests the behavior of the structure presents a greater vertical deformation with the condition of two screws, noting that the maximum vertical deformation difference is much less with the condition of four screws since it gives better support to the structure, supporting a greater load. The total height is 103 $\mathrm{mm}$ and $440 \mathrm{~g}$. The fuse complies with the M8524A2 standard, a delay time of $4.5 \pm$ $0.5 \mathrm{~s}$. These values coincide with the real ones of the IM26 grenade.

The grenade body supports, on average, a maximum load of 2874 Newtons and vertical deformation of $2.79 \mathrm{~mm}$.

The construction of weapon elements for military use presents a high level of restriction in terms of information, therefore, the implementation of an IM-26 type hand grenade model is done following the security, care, and communication protocols that the military institution maintains, in this order of ideas. The emulation of this artifact took place with the NCO military school and the Indumil military manufacturing industry support, who have the power to handle these types of elements and likewise to be able to carry out a scanning process and to use designs that would not otherwise be freely available; this makes it impossible to carry out a patent process on the physical structure of this element.

The Synapse radiofrequency operation module use, turned out to be the most suitable option so far due to the range it handles, is a technology that manages to transmit at a distance of 1 mile (1600 m approx.) and with $2.4 \mathrm{GHz}$ operating band on different channels. This was presented as an advantage, since in the signal transmission and reception test exercise we worked with RF transmission elements at frequencies of $433 \mathrm{MHz}$ [23] and with ranges not greater than 100 and $200 \mathrm{~m}$. In this way it was possible to determine that the free experimentation operating frequencies are in channels around the mentioned frequency (433 MHz).

The material used (ABS) is a sufficiently strong material, which needs a high temperature so that it can be injected by the 3D printer, therefore, the different types of printers that were used by the researchers sometimes do not reach the appropriate temperature, and the injection does not end up being precise, showing holes and porosity in the model in each layer. For this reason, and thinking about a future production chain, the results show that the injection of the material in a steel mold was the most appropriate option.

The tests carried out on the device resulted in the possibility of achieving a product that can be reused on more than one occasion, this implies that a greater number of throwing exercises can be performed and improve the technical skills of 
the non-commissioned officer in terms of throwing hand grenades. The only scenario where the product is not recoverable is when it falls into a surface with water and the grenade is submerged due to the seeping of water through its folds, wetting the transmitter circuit and its power supply.

The delivered prototype complies with the usage requirement of at least 10 times, with the characteristic size and color and the similar mass to the original version, as well as the time after uninsured and the sound execution time after being released. These last two parameters are fundamental for the grenade throwing exercise in the combat course stage since it allows instructors on the training ground to make decisions and have control of each of the throws, such as the case of not having the grenade unlocked for more than 5 seconds and not involuntarily removing its safety lever before being thrown or what is known in the exercise as "milking" the grenade, an act that causes several accidents.

The benefits of using this type of non-explosive simulation hand grenade are many. Among the most relevant are the security of the military or police in the practice of this exercise, the skills developed by the easy handling of the prototype, and its resemblance to a real IM26 grenade; even though the cost of the simulation grenade is higher than the real grenade, this in real terms is much lower, if one takes into account that the simulation grenade is reusable, allowing for a larger number of launches compared to the single launch of the real one.

\section{REFERENCES}

[1] D. Ampuła, "Application of Neural Networks in the Tests of Hand Grenade Fuses," Bull. Mil. Univ. Technol., vol. 68, no. 1, pp. 197-212. 2019, doi: https://doi.org/10.5604/01.3001.0013.1480.

[2] I. Aznar Díaz, et al., "La tecnología móvil de Realidad Virtual en educación: una revisión del estado de la literatura científica en España," EDMETIC, vol. 7, no. 1, 256. 2018, doi: https://doi. org/10.21071/edmetic.v7i1.10139.

[3] C.J. Campagnuolo, et al., US5246372A - Training grenade. [Online]. Available: https://patents. google.com/patent/US5246372, (2010).

[4] D. Chen, et al., "SmokeGrenade: A key generation protocol with artificial interference in wireless network," in: Proceedings - IEEE 10th International Conference on Mobile Ad-Hoc and Sensor Systems, MASS 2013. pp. 200-208. 2013, doi: https://doi.org/10.1109/MASS.2013.73. 
[5] E.W. Eidson, US5018449A - Paint dispersing training grenade, https://patents.google.com/ patent/US5018449A/en?oq=Paint+dispersing+training+grenade+(US5018449A), (2008).

[6] E.A. Filippi, US3492945A - Practice grenade. [Online]. Available: https://patents.google.com/ patent/US3492945, (1987).

[7] V. Grabe, S.T. Nuske, "Long distance visual ground-based signaling for unmanned aerial vehicles," in: IEEE International Conference on Intelligent Robots and Systems. pp. 4976-4983 Institute of Electrical and Electronics Engineers Inc. (2016), doi: https://doi.org/10.1109/ IROS.2016.7759731.

[8] V.B. Gromov, et al. RU55462U1 - LIGHT SOUND Grenade (OPTIONS). [Online]. Available: https://patents.google.com/patent/RU55462U1/en?q=Light+sound+grenade\&oq=Light tand+sound+grenade+.

[9] HFI Pyrotechnics Inc, M116A1 - Simulator Hand Grenade, Prescott (2020).

[10] Indumil, Granada IMC MG M26 HE - Indumil. [Online]. Available: https://www.indumil.gov.co/ product/granada-imc-mg-m26-he/

[11] D. Martins, et al., "Caracterización de las propiedades mecánicas de los cuerpos de prueba ABS confeccionados con diferentes parámetros de extrusión vía impresión 3D," Rev. Iberoam. Polímeros., vol. 17, pp. 303-309, 2016.

[12] S. Min, S. Lee, "Developing Vehicle-launched Smoke Grenade M\&S of Moderate-resolution for Applications in Engagement Simulation,” J. Korea Soc. Simul., vol. 28, no. 2, pp. 59-69. 2019, doi https://doi.org/10.9709/JKSS.2019.28.2.059.

[13] P.A. Osorio Villa, et al., "El Uso de Simuladores Educativos para el Desarrollo de Competencias en la Formación Universitaria de Pregrado," Rev. Q., vol. 7, no. 13, pp. 1-23. 2012.

[14] D.E. Rojas-Ballesteros, et al., "Mobile Classroom for Military Tactical Training in Cavalry Mission Planning," Ing. Solidar., vol. 15, no. 29, pp. 1-20. 2019. https://doi.org/10.16925/ 2357-6014.2019.03.11.

[15] Saab Defense and Security, HGS2 Hand Grenade Simulator User Manual. (2016).

[16] Synapse Wireless ${ }^{\circledR}$, Synapse RF200PD1 Engine. (2013).

[17] S.K. Yoo, et al., A Methodology for Effectiveness Analysis of Future Weapon System Using a PLAF Based Simulation System. (2012), doi: https://doi.org/10.1007/978-4-431-54216-2_37. 
[18a]Zen Technologies Limited, Hand Grenade Simulator (HE36S ${ }^{\circledR}$ ). [Online]. Available: https:// www.zentechnologies.com/zen_hand_grenade_simulator.html

[18b]C.M.R.Sánchez,C.J.Cortés, “Rapidcastingynuevastecnologíasenel procesodemicrofundición,” Ingeniería elnvestigación, vol. 26, no. 1, pp. 110-119.2006. [Online]. Available: http://www.scielo.org.co/scielo.php?script=sci_arttext\&pid=S0120-56092006000100014\&lng=en\&tlng=es.

[19] I.A. Domínguez, L. Romero, M.M. Espinosa, M. Domínguez, "Impresión 3D de maquetas y prototipos en arquitectura y construcción," Revista de la construcción, vol. 12, no. 2, pp. 39-53, doi: https://dx.doi.org/10.4067/S0718-915X2013000200004

[20] D. Juarez Varón, R. Balart Gimeno, S. Ferrándiz Bou, M.A. Peydró Rasero, "Estudio y análisis del moldeo por inyección de materiales poliméricos termoplásticos," 3C Tecnología. Glosas De Innovación Aplicadas a La Pyme, vol. 1, no. 3. [Online]. Available: http://ojs.3ciencias.com/ index.php/3c-tecnologia/article/view/79

[21] O. Schinagl, Getting Started with Cubieboard, Birmingham B3 2PB, UK, Pack Open Source.

[22] J. V. Molina Osejo, Caracterización de materiales termoplásticos de ABS y PLA semi - rígido impresos en 3D con cinco mallados internos diferentes. Quito: EPN. 2016.

[23] G. Echeverry Vásquez, Y. Cabezas Burbano, N. Olarte López, "Normatividad para las frecuencias ISM orientada hacia aplicaciones de dispositivos Xbee-802.15.4-Pro.," INGE CUC, vol. 10, no. 2, pp. 81 - 90. [Online]. Available: https://revistascientificas.cuc.edu.co/ingecuc/article/ view/494 